\title{
INFLUENCE OF ENVIRONMENTAL VARIATIONS ON THE FORMATION OF MICROHABITATS WITHIN A FRAGMENT OF SEASONALLY DRY TROPICAL FOREST - SDTF, BRAZIL ${ }^{1}$
}

\author{
Gabriela Gomes Pires de Paula ${ }^{2 *}$, Rubens Manoel dos Santos ${ }^{3}$, Gisele Cristina de Oliveira Menino ${ }^{4}$, \\ Deborah Mattos Guimarães Apgaua ${ }^{5}$, Diego Gualberto Sales Pereira ${ }^{3}$, Cléber Rodrigo de Souza² and \\ Marco Aurélio Leite Fontes ${ }^{3}$
}

\footnotetext{
${ }^{1}$ Received on 29.08.2017 accepted for publication on 25.05.2018.

${ }^{2}$ Universidade Federal de Lavras, Programa de Pós-Graduação em Engenharia Florestais, Lavras, MG-Brasil. E-mail: <gabyfloresta@gmail.com>and <crdesouza@hotmail.com>.

${ }^{3}$ Universidade Federal de Lavras, Departamento de Ciências Florestais, Lavras, MG-Brasil. E-mail: <rubensmanoel.dcf.ufla.br>, $<$ diegogspereira@gmail.com> and < fontes@dcf.ufla.br>.

${ }^{4}$ Instituto Federal Goiano, Departamento de Ciências Biológicas, Rio Verde, GO-Brasil. E-mail: < giselecristina.biologa@yahoo.com.br>. ${ }^{5}$ Centre for Tropical Environmental and Sustainability Sciences, College of Marine and Environmental Sciences, James Cook University, Cairns, Qld, Austrália. E-mail: <deborah_ufla@yahoo.com.br>.

*Corresponding author.
}

\begin{abstract}
Caatinga represents one of the two major centers of Seasonally Dry Tropical Forests (SDTF) and is completely inserted in the Brazilian territory. The present work aimed to evaluate the structure of two micro-environments and relate them to environmental variables. Twenty $20 \times 20 \mathrm{~m}$ plots were placed in which we measured the height and $\mathrm{CBH}$ and made the botanical identification of all trees with $\mathrm{CBH} \geq 10$ $\mathrm{cm}$. The CCA and indicator species analysis presented a clear distribution of species according to the microenvironments. We concluded that the presence of limestone slabs provided the formation of microhabitats, thus influencing the distribution and composition of tree species, what characterized the phytoecological unit here referred as "furados".
\end{abstract}

Keywords: Environmental variations, Beta diversity, Limestone slabs.

\section{INFLUÊECIA DAS VARIAÇÕES AMBIENTAIS NA FORMAÇÃO DE MICRO- HABITATS EM UM FRAGMENTO DE FLORESTAS TROPICAIS SAZONALMENTE SECAS, BRASIL}

\begin{abstract}
RESUMO - A caating a corresponde a um dos dois maiores núcleos das Florestas Tropicais Sazonalmente Secas (FTSS) e se encontra totalmente inserida no território brasileiro. Objetivou-se com este estudo avaliar a estrutura de dois micro-habitats relacionando-a com as variáveis ambientais. Foram alocadas 24 parcelas, nas quais mensuramos o CAP e fizemos a identificação botânica de todos os individuos arbóreos com CAP $\geq 10 \mathrm{~cm}$. Com a presença de lajedos de calcário na área, foi possível distinguir dois micro-habitats. A CCA e a análise de espécies indicadoras mostraram uma nítida distribuição das espécies de acordo com os micro-habitats. Concluímos que a presença dos lajedos de calcário proporcionou a formação dos microhabitats, influenciando na distribuição e composição das espécies arbustiva-arbóreas, caracterizando a unidade fitoecológica aqui denominada como "furados".
\end{abstract}

Palavras-Chave: Variações ambientais, “Furados”, Diversidade beta. 


\section{INTRODUCTION}

The Seasonally Dry Tropical Forests (SDTF) represent disjoint vegetation formations annually exposed to water deficits for a period greater than or equal to five months that share species and genera adapted to water scarcity (Moro et al., 2016). Pennington et al., (2009) proposed SDTF as one of the leading world biomes or a global metacommunity.

In this context, we highlight Brazilian Caatinga as the largest semi-arid tropical ecoregion of South America and one of the two largest cores of SDTF (Caetano et al., 2008; Moro et al., 2016). Caatinga presents a great physiognomic and floristic variation resulting from the interaction of a set of factors, mainly rainfall and soil moisture (Prado, 2005; Santos et al., 2012), and shelter remnants of other vegetation types, such as savannah and rupestrian fields. Additionally, lithological differences at regional or local scale contributes to the vegetation mosaic of Caatinga (Rodal et al., 2008; Santos et al., 2012). Despite of such particularities, the Caatinga has been suffering intensive exploration and degradation mainly by agricultural practice, logging (wood and coal) and expansion of farmland, thus causing great environmental impacts and decimating the remnants of arboreal Caatinga in the northern region of Minas Gerais (Santos et al., 2008).

The present study aimed to test the influence of micro-environmental characteristics on species richness and the horizontal structure of the shrubby tree community of a Seasonally Dry Tropical Forest (SDTF) fragment and test whether the presence of limestone slags influences the distribution and composition of species in this fragment.

\section{METHODS}

\subsection{Area of study}

The present work was carried out in a forest remnant located in the municipality of Montalvânia, northern Minas Gerais (Fig. 1) The climate is tropical semi-arid (Bsh), with hot and dry summers. Mean annual temperature and precipitation are $23{ }^{\circ} \mathrm{C}$ and $935 \mathrm{~mm}$ year $^{-1}$ (Embrapa, 2012), respectively, with rainfall concentrated from November to January.

The study area presents a flat relief with depressions associated with limestone slabs which sometimes are exposed providing areas of retention and accumulation

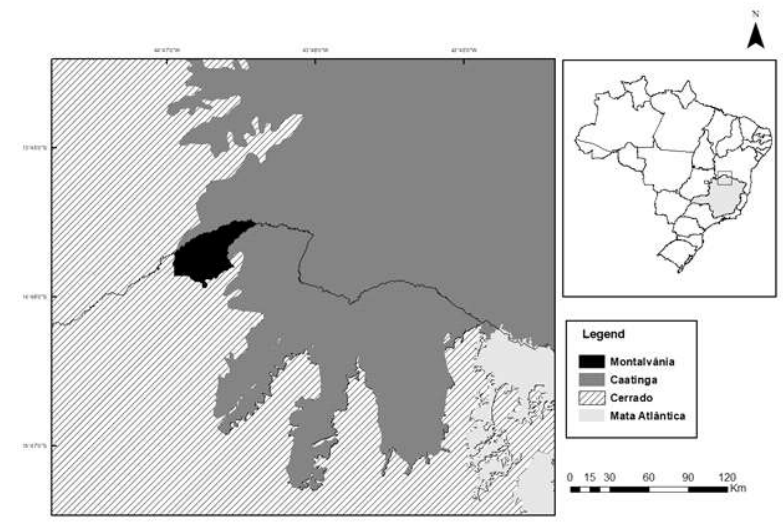

Figure 1- Location of the study area. Figura 1-Localização da área de estudo.

of water in the rainy season. The sparse vegetation occurs in function of the presence of shallow soils leading to empty spaces in the landscape, which are popularly called "furados" (Brandão and Gavilanes, 1994; Santos et al., 2012). The presence of slabs provides two distinct microhabitats to the fragment in which we find both vegetation on deep soils and limestone slabs.

The study area is inserted in a region with Arboreal Caatinga as predominant phytophysiognomy (Santos et al., 2012), which is part of the large field of Tropical Seasonally Dry Forests. The fragment presents a good condition of conservation, although cattle was observed in some plots.

The geological formation was classified based on the exposed rock. The classification was performed by the team of Laboratory of Mineralogy and Soil Chemistry of the Federal University of Lavras.

\subsection{Dataset}

In general, 24 plots of $400 \mathrm{~m}^{2}$ were placed $30 \mathrm{~m}$ apart from each other. The plots were distributed in four transects with a minimum distance of $50 \mathrm{~m}$ between tansects, to cover the microenvironmental variations, characterized by the presence of slabs of limestone. Data collection was concluded on January 2011.

The criterion of inclusion for arboreal individuals was the $\mathrm{CBH}$ (circumference at breast height, $1.30 \mathrm{~m}$ from the ground) $\geq 10 \mathrm{~cm}$. For individuals with bifurcations below the $\mathrm{CBH}$ we followed the procedures recommended by Scolforo and Melo (1997).

Revista Árvore. 2018;42(2):e420211 
Botanical identifications were made in the field as well as consulting experts and herbariums. The classification system used follows the APG II adopting Souza and Lorenzi (2005) for the family level. Synonyms and new species combinations were made using the REFLORA (2014) database.

We used parameters based on Mueller-Dombois and Ellemberg (1974) to describe the fragment and each microhabitat horizontally (Supplementary Material).

\subsection{Soil Variables}

One soil sample was taken from each plot at a depth of 0 to $10 \mathrm{~cm}$ to characterize the physical and chemical aspects. Chemical and physical analyzes were performed by Laboratory of Soil Analyses of the Federal University of Viçosa, measuring the following parameters: $\mathrm{pH}$, $\mathrm{P}, \mathrm{K}, \mathrm{Na}, \mathrm{Ca}^{2+}, \mathrm{Mg}^{2+}, \mathrm{Al}^{3+}, \mathrm{SB},(\mathrm{t}),(\mathrm{T}), \mathrm{V}, \mathrm{m}$, organic matter, $\mathrm{Zn}, \mathrm{Fe}, \mathrm{Mn}, \mathrm{Cu}$, sand, silt and clay. The results of soil analyses were used to compose the environmental matrix of the Canonical Correspondence Analysis (CCA). In function of the presence of limestone slabs we measured the depth using a bar of $1.50 \mathrm{~m}$ to make perforations in the soil. Areas with water accumulation, presence of exposed limestone and soil depth lower than one meter were denominated "furados". On the other hand, plots with soil depth greater than one meter were classified as "vegetation on deep soils".

\subsection{Data Analysis}

In order to respond to the proposed objective, the following steps were conducted: i) phytosociological characterization of each microhabitat by means of the structural parameters of absolute and relative density (AD and RD), frequency, dominance (ADo) and importance value (Mueller-Dombois and Ellemberg, 1974), besides the diversity indices of Shannon ( $\mathrm{H}^{\circ}$ ) and Pielou equability ( $\left.\mathrm{J}^{\prime}\right)$ in order to analyze whether the environments have different composition and structure; ii) division of individuals (with sampling $\mathrm{n}$ greater than 25 in both microhabitats) in diametric classes of increasing amplitude to compensate the concentration of individuals in the smaller classes (Oliveira Filho et al., 2001); iii) identification of indicator species of each microhabitat through the indicator species analysis (package "indicspecies" of software R); iv) calculation of the Whittaker beta diversity (Whittaker, 1960) on each microhabitat in order to evaluate whether the replacement of species within each unit is distinct; v) identification of environmental variables that have significant effect on species distribution and differentiation of microhabitats by means of the Canonical Correspondence Analysis (CCA). This analysis is used when the objective is to obtain a better relationship of environmental variables and species abundance (Kent and Coker, 1992). The selection and use of parameters in the environmental matrix were made based on the results of an analysis of two independent samples using Student's t-test. The selected variables were transformed according to Zar (2010) and finally the Monte Carlo test was carried out to assess the significance of results (Ter Braak, 1988). The multivariate analysis, CCA and beta diversity assessments were conducted using the software R (R Development Core Team, 2015), package vegan (Oksanen, 2010).

\section{RESULTS}

\subsection{Dataset}

Overall, 1375 individuals belonging to 58 species, 52 genera and 20 botanical families were sampled. The absolute dominance and density were $32.96 \mathrm{~m}^{2} \mathrm{ha}^{-1}$ and 1375 ind $\mathrm{ha}^{-1}$, respectively (Table1).

The most representative family regarding number of species was Fabaceae (17), followed by Malvaceae (5), Anacardiaceae, Cactaceae and Euphorbiaceae (the three with four species). Bignoniaceae stood out regarding abundance in the survey (344), representing $25 \%$ of the sampled individuals which dominance was provided by the species Handroanthus ochraceus (Cham.) Mattos (213). This species is widely distributed in deciduous forests and edges of semi-deciduous forests (Santos et al., 2011).

The Shannon-Wiener diversity index $\left(\mathrm{H}^{\prime}\right)$ for the community was estimated at 3.02 nats ind- 1 and the Pielou equability (J') at 0.74 . Regarding microhabitats, H' was estimated at 2.99 nats ind ${ }^{-1}$ and 2.55 nats ind $^{-1}$, while $\mathrm{J}^{\text {' was }}$ 0.79 and 0.67 for "furados" and vegetation in deep soil, respectively.

\subsection{Soil Variables}

The geological formation classified as limestone of Serra de Santa Helena from Neoproterozoic was observed in the studied fragment, which belongs to the Bambuí group. This formation is the responsible by the presence of "furados" in this fragment.

The measurement of depths resulted in a categorical variable for which we identified the plots located on 
Table 1 - Phytosociological table of the community and microhabitats of a fragment in Montalvânia - MG.

Tabela 1 - Tabela fitossociológica da comunidade e dos microhabitats de um fragmento em Montalvânia - MG

\begin{tabular}{|c|c|c|c|c|c|c|c|c|c|c|c|c|c|c|c|}
\hline \multirow[t]{2}{*}{ Family/Species } & \multicolumn{5}{|c|}{ Community } & \multicolumn{5}{|c|}{ Furados } & \multicolumn{5}{|c|}{ Vegetation in Deep Soil - VDS } \\
\hline & IN & $\mathrm{AD}$ & $\mathrm{AF}$ & ADo & IV & IN & $\mathrm{AD}$ & $\mathrm{AF}$ & ADo & IV & IN & $\mathrm{AD}$ & $\mathrm{AF}$ & ADo & IV \\
\hline \multicolumn{16}{|l|}{ ANACARDIACEAE } \\
\hline $\begin{array}{l}\text { Cyrtocarpa caatingae J.D.Mitch. } \\
\text { \& Daly }\end{array}$ & 1 & 1.0 & 4.0 & 0.03 & 0.46 & - & - & - & - & - & 1 & 2.50 & 10.00 & 0.07 & 1.18 \\
\hline Myracrodruon urundeuva Allemão & 99 & 99.0 & 84.0 & 3.90 & 25.45 & 36 & 60.00 & 73.33 & 2.27 & 16.95 & 63 & 157.50 & 100.00 & 6.34 & 41.30 \\
\hline Schinopsis brasiliensis Engl. & 3 & 3.0 & 12.0 & 0.01 & 1.17 & - & - & - & - & - & 3 & 7.50 & 30.00 & 0.03 & 2.87 \\
\hline Spondias tuberosa Arruda & 11 & 11.0 & 32.0 & 0.49 & 4.75 & 11 & 18.33 & 53.33 & 0.82 & 7.86 & - & - & - & - & - \\
\hline \multicolumn{16}{|l|}{ APOCYNACEAE } \\
\hline Aspidosperma pyrifolium Mart. & 4 & 4.0 & 8.0 & 0.05 & 1.05 & 4 & 6.67 & 13.33 & 0.08 & 1.82 & - & - & - & - & - \\
\hline \multicolumn{16}{|l|}{ ARALIACEAE } \\
\hline Aralia excelsa (Griseb.) J.Wen & 7 & 7.0 & 24.0 & 0.13 & 2.73 & 4 & 6.67 & 20.00 & 0.16 & 2.55 & 3 & 7.50 & 30.00 & 0.07 & 3.03 \\
\hline \multicolumn{16}{|l|}{ BIGNONIACEAE } \\
\hline $\begin{array}{l}\text { Arrabidaea bahiensis (Schauer) } \\
\text { Sandwith \& Moldenke }\end{array}$ & 73 & 73.0 & 36.0 & 0.68 & 10.11 & 5 & 8.33 & 20.00 & 0.18 & 2.75 & 68 & 170.00 & 60.00 & 1.42 & 19.79 \\
\hline $\begin{array}{l}\text { Handroanthus ochraceus } \\
\text { (Cham.) Mattos }\end{array}$ & 213 & 213.0 & 60.0 & 2.14 & 26.58 & 36 & 60.00 & 40.00 & 1.10 & 11.31 & 177 & 442.50 & 90.00 & 3.72 & 46.51 \\
\hline Tabebuia reticulata A.H.Gentry & 58 & 58.0 & 56.0 & 0.32 & 9.46 & 12 & 20.00 & 53.33 & 0.08 & 6.04 & 46 & 115.00 & 60.00 & 0.67 & 13.79 \\
\hline \multicolumn{16}{|l|}{ BORAGINACEAE } \\
\hline Auxemma oncocalyx (Allemão) Taub. & 6 & 6.0 & 12.0 & 0.04 & 1.47 & 4 & 6.67 & 13.33 & 0.03 & 1.68 & 2 & 5.00 & 10.00 & 0.05 & 1.26 \\
\hline \multicolumn{16}{|l|}{ BURSERACEAE } \\
\hline $\begin{array}{l}\text { Commiphora leptophloeus } \\
\text { (Mart.) J.B.Gillet }\end{array}$ & 75 & 75.0 & 68.0 & 3.02 & 19.82 & 68 & 113.33 & 93.33 & 4.71 & 29.69 & 7 & 17.50 & 30.00 & 0.49 & 5.23 \\
\hline \multicolumn{16}{|l|}{ CACTACEAE } \\
\hline Cereus jamacaru DC. & 3 & 3.0 & 4.0 & 0.10 & 0.83 & 3 & 5.00 & 6.67 & 0.17 & 1.40 & - & - & - & - & - \\
\hline Pereskia bahiensis Gürke & 12 & 12.0 & 20.0 & 0.08 & 2.64 & 11 & 18.33 & 26.67 & 0.10 & 3.94 & 1 & 2.50 & 10.00 & 0.04 & 1.07 \\
\hline $\begin{array}{l}\text { Pilosocereus gounellei (F.A.C.Weber) } \\
\text { Byles \& G.D.Rowley }\end{array}$ & 3 & 3.0 & 12.0 & 0.02 & 1.21 & 3 & 5.00 & 20.00 & 0.04 & 2.07 & - & - & - & - & - \\
\hline Pilosocereus pachycladus F. Ritter & 7 & 7.0 & 12.0 & 0.12 & 1.79 & 7 & 11.67 & 20.00 & 0.20 & 3.09 & - & - & - & - & - \\
\hline \multicolumn{16}{|l|}{ CARICACEAE } \\
\hline Jacaratia corumbensis Kuntze & 1 & 1.0 & 4.0 & 0.001 & 0.38 & - & - & - & - & - & 1 & 2.50 & 10.00 & 0.003 & 0.93 \\
\hline \multicolumn{16}{|l|}{ COMBRETACEAE } \\
\hline Combretum leprosum Mart. & 161 & 161.0 & 48.0 & 0.84 & 17.93 & 25 & 41.67 & 20.00 & 0.23 & 5.85 & 136 & 340.00 & 90.00 & 1.76 & 33.11 \\
\hline Terminalia phaeocarpa Eichler & 3 & 3.0 & 4.0 & 0.04 & 0.63 & 3 & 5.00 & 6.67 & 0.06 & 1.11 & - & - & - & - & - \\
\hline \multicolumn{16}{|l|}{ EUPHORBIACEAE } \\
\hline Cnidoscolus oligandrus (Müll.Arg.) Pax & 2 & 2.0 & 8.0 & 0.09 & 1.03 & 2 & 3.33 & 13.33 & 0.15 & 1.71 & - & - & - & - & - \\
\hline Manihot tripartita(Spreng.) Müll.Arg. & 2 & 2.0 & 8.0 & 0.01 & 0.79 & 1 & 1.67 & 6.67 & 0.01 & 0.67 & 1 & 2.50 & 10.00 & 0.02 & 0.98 \\
\hline Sapium argutum(Müll.Arg.) Huber & 12 & 12.0 & 36.0 & 0.03 & 3.73 & 10 & 16.67 & 46.67 & 0.05 & 5.16 & 2 & 5.00 & 20.00 & 0.01 & 1.87 \\
\hline Stillingia saxatilis Müll.Arg. & 46 & 46.0 & 64.0 & 0.18 & 8.77 & 40 & 66.67 & 80.00 & 0.24 & 12.67 & 6 & 15.00 & 40.00 & 0.08 & 4.25 \\
\hline \multicolumn{16}{|l|}{ FABACEAE } \\
\hline Acosmium lentiscifolium $\mathrm{Schott}$ & 6 & 6.0 & 20.0 & 0.02 & 2.03 & - & - & - & - & - & 6 & 15.00 & 50.00 & 0.05 & 4.94 \\
\hline Amburana cearensis (Allemão) A.C.Sm. & 21 & 21.0 & 28.0 & 0.52 & 5.25 & 18 & 30.00 & 26.67 & 0.64 & 6.39 & 3 & 7.50 & 30.00 & 0.35 & 4.10 \\
\hline Anadenanthera colubrina (Vell.) Brenan & 12 & 12.0 & 32.0 & 0.46 & 4.73 & 5 & 8.33 & 26.67 & 0.22 & 3.35 & 7 & 17.50 & 40.00 & 0.83 & 7.33 \\
\hline Centrolobium sclerophyllum H.C.Lima & 2 & 2.0 & 8.0 & 0.04 & 0.89 & - & - & - & - & - & 2 & 5.00 & 20.00 & 0.11 & 2.25 \\
\hline Coursetia rostrata Benth. & 1 & 1.0 & 4.0 & 0.001 & 0.38 & 1 & 1.67 & 6.67 & 0.001 & 0.66 & - & - & - & - & - \\
\hline Dalbergia cearensis Ducke & 11 & 11.0 & 20.0 & 0.17 & 2.84 & 1 & 1.67 & 6.67 & 0.02 & 0.69 & 10 & 25.00 & 40.00 & 0.40 & 6.07 \\
\hline Enterolobium timbouva Mart. & 8 & 8.0 & 28.0 & 0.31 & 3.67 & 4 & 6.67 & 20.00 & 0.36 & 3.08 & 4 & 10.00 & 40.00 & 0.23 & 4.57 \\
\hline $\begin{array}{l}\text { Lonchocarpus montanus A.M.G. } \\
\text { Azevedo ex M.J.Silva \& A.M.G.Azevedo }\end{array}$ & 3 & 3.0 & 4.0 & 0.01 & 0.56 & - & - & - & - & - & 3 & 7.50 & 10.00 & 0.03 & 1.30 \\
\hline Luetzelburgia andradelimae H.C.Lima & 37 & 37.0 & 48.0 & 0.24 & 7.09 & 21 & 35.00 & 66.67 & 0.30 & 8.98 & 16 & 40.00 & 20.00 & 0.15 & 4.41 \\
\hline Machaerium acutifolium Vogel & 13 & 13.0 & 24.0 & 0.12 & 3.15 & 2 & 3.33 & 13.33 & 0.01 & 1.34 & 11 & 27.50 & 40.00 & 0.29 & 5.78 \\
\hline Machaerium leucopterum Vogel. & 8 & 8.0 & 4.0 & 0.36 & 1.97 & - & - & - & - & - & 8 & 20.00 & 10.00 & 0.90 & 5.39 \\
\hline
\end{tabular}

Revista Árvore. 2018;42(2):e420211 
Table 1...

Tabela 1...

\begin{tabular}{|c|c|c|c|c|c|c|c|c|c|c|c|c|c|c|c|}
\hline & & & & & & & & & & & & & & & \\
\hline 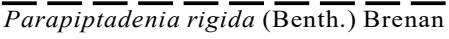 & $\overline{6}$ & 6.0 & $\overline{16.0}$ & $\overline{0.05}$ & $\overline{1.82}$ & $\overline{1}$ & $1 . \overline{67}$ & $\overline{6} . \overline{7}$ & $\overline{0.01}$ & $0 . \overline{67}$ & 5 & $\overline{12.50}$ & $3 \overline{0.00}$ & $\overline{0.12}$ & $3 . \overline{52}$ \\
\hline Peltophorum dubium (Spreng.) Taub. & 1 & 1.0 & 4.0 & 0.16 & 0.87 & - & - & - & - & - & 1 & 2.50 & 10.00 & 0.40 & 2.48 \\
\hline Platymiscium floribundum Vogel & 1 & 1.0 & 4.0 & 0.002 & 0.38 & 1 & 1.67 & 6.67 & 0.003 & 0.66 & - & - & - & - & - \\
\hline Poecilanthe falcata (Vell.) Heringer & 1 & 1.0 & 4.0 & 0.001 & 0.38 & - & - & - & - & - & 1 & 2.50 & 10.00 & 0.003 & 0.93 \\
\hline $\begin{array}{l}\text { Poincianella pluviosa (DC.) } \\
\text { L.P.Queiroz }\end{array}$ & $\begin{array}{c}20 \\
1\end{array}$ & 120.0 & 56.0 & 1.46 & 17.43 & 82 & 136.67 & 46.67 & 1.58 & 19.95 & 38 & 95.00 & 70.00 & 1.27 & 15.75 \\
\hline Sweetia fruticosa Spreng. & 4 & 4.0 & 16.0 & 0.06 & 1.70 & 1 & 1.67 & 6.67 & 0.04 & 0.75 & 3 & 7.50 & 30.00 & 0.09 & 3.12 \\
\hline LYTHRACEAE & & & & & & & & & & & & & & & \\
\hline Lafoensia pacari A.St.-Hil. & 5 & 5.0 & 12.0 & 0.04 & 1.41 & 5 & 8.33 & 20.00 & 0.07 & 2.45 & - & - & - & - & - \\
\hline MALPIGHIACEAE & & & & & & & & & & & & & & & \\
\hline Ptilochaeta bahiensisTurcz. & 6 & 6.0 & 24.0 & 0.03 & 2.37 & 5 & 8.33 & 33.33 & 0.03 & 3.35 & 1 & 2.50 & 10.00 & 0.04 & 1.06 \\
\hline Ptilochaeta glabra Nied. & 1 & 1.0 & 4.0 & 0.002 & 0.38 & - & - & - & - & - & 1 & 2.50 & 10.00 & 0.01 & 0.94 \\
\hline MALVACEAE & & & & & & & & & & & & & & & \\
\hline $\begin{array}{l}\text { Cavanillesia arborea (Willd.) } \\
\text { K.Schum. }\end{array}$ & 15 & 15.0 & 32.0 & 12.06 & 40.14 & 14 & 23.33 & 46.67 & 17.15 & 51.04 & 1 & 2.50 & 10.00 & 4.43 & 18.13 \\
\hline Ceiba pubiflora (A.St.-Hil.) K.Schum. & 3 & 3.0 & 12.0 & 0.39 & 2.33 & 3 & 5.00 & 20.00 & 0.66 & 3.70 & - & - & - & - & - \\
\hline $\begin{array}{l}\text { Pseudobombax marginatum } \\
\text { (A.St.-Hil.) A.Robyns }\end{array}$ & 1 & 1.0 & 4.0 & 0.01 & 0.40 & 1 & 1.67 & 6.67 & 0.01 & 0.68 & - & - & - & - & - \\
\hline $\begin{array}{l}\text { Pseudobombax simplicifolium } \\
\text { A.Robyns }\end{array}$ & 38 & 38.0 & 40.0 & 2.25 & 12.65 & 38 & 63.33 & 66.67 & 3.75 & 20.66 & - & - & - & - & - \\
\hline Sterculia striata A.St.-Hill. \& Naudin & 12 & 12.0 & 20.0 & 0.31 & 3.34 & 8 & 13.33 & 20.00 & 0.35 & 3.63 & 4 & 10.00 & 20.00 & 0.25 & 3.09 \\
\hline MELIACEAE & & & & & & & & & & & & & & & \\
\hline Cedrela fissilis Vell. & 12 & 12.0 & 28.0 & 0.57 & 4.75 & 11 & 18.33 & 40.00 & 0.65 & 6.39 & 1 & 2.50 & 10.00 & 0.46 & 2.70 \\
\hline MYRTACEAE & & & & & & & & & & & & & & & \\
\hline Eugenia uniflora $\mathrm{L}$. & 166 & 166.0 & 60.0 & 0.58 & 18.42 & 127 & 211.67 & 66.67 & 0.80 & 26.14 & 39 & 97.50 & 50.00 & 0.25 & 10.37 \\
\hline POLYGONACEAE & & & & & & & & & & & & & & & \\
\hline Coccoloba schwackeana Lindau & 6 & 6.0 & 16.0 & 0.05 & 1.81 & 5 & 8.33 & 20.00 & 0.08 & 2.47 & 1 & 2.50 & 10.00 & 0.01 & 0.95 \\
\hline Ruprechtia apetala Weddell & 22 & 22.0 & 56.0 & 0.17 & 6.40 & 14 & 23.33 & 66.67 & 0.20 & 7.67 & 8 & 20.00 & 40.00 & 0.13 & 4.73 \\
\hline Ruprechtia laxiflora Meisn. & 1 & 1.0 & 4.0 & 0.003 & 0.39 & - & - & - & - & - & 1 & 2.50 & 10.00 & 0.01 & 0.94 \\
\hline RHAMNACEAE & & & & & & & & & & & & & & & \\
\hline Ziziphus cotinifolia Reissek & 1 & 1.0 & 4.0 & 0.001 & 0.38 & - & - & - & - & - & 1 & 2.50 & 10.00 & 0.003 & 0.93 \\
\hline Ziziphus joazeiro Mart. & 2 & 2.0 & 4.0 & 0.02 & 0.52 & - & - & - & - & - & 2 & 5.00 & 10.00 & 0.05 & 1.26 \\
\hline RUBIACEAE & & & & & & & & & & & & & & & \\
\hline Chomelia pohliana Müll.Arg. & 4 & 4.0 & 4.0 & 0.03 & 0.69 & 4 & 6.67 & 6.67 & 0.05 & 1.23 & - & - & - & - & - \\
\hline Randia armata (Sw.) DC. & 16 & 16.0 & 32.0 & 0.06 & 3.80 & 12 & 20.00 & 40.00 & 0.09 & 5.07 & 4 & 10.00 & 20.00 & 0.02 & 2.20 \\
\hline SALICACEAE & & & & & & & & & & & & & & & \\
\hline Casearia selloana Eichl. & 6 & 6.0 & 12.0 & 0.04 & 1.48 & - & - & - & - & - & 6 & 15.00 & 30.00 & 0.11 & 3.60 \\
\hline Prockia crucis P.Browne ex L. & 1 & 1.0 & 4.0 & 0.001 & 0.38 & 1 & 1.67 & 6.67 & 0.002 & 0.66 & - & - & - & - & - \\
\hline TOTAL & 1375 & 1375.0 & 1308.0 & 32.96 & 300.00 & 670 & 1116.67 & 1320.00 & 37.77 & 300.00 & 705 & 1762.50 & 1290.00 & 25.763 & 300.00 \\
\hline
\end{tabular}

Legend: IN- individuals number; AD - Absolute density; AF- Absolute frequency; ADo- Absolute dominance; IV- Importance value.

deep soil (9 plots) or "furados" (15 plots): P1 to P6 ("furados"); P7 and P8 (vegetation in deep soil); P9 to P14 (“furados"); P15 to P21 (vegetation in deep soil) and P22 to P24 ("furados").

\subsection{Data Analysis}

Differences were observed between microhabitat, both regarding species composition and community structure, resulting in peculiarities and exclusiveness of each microhabitat.
"Furados" presented 670 individuals of 18 families and 44 species, with as Fabaceae the most abundant (137) and richest in species (11). The number of individuals per area (AD) showed that Eugenia uniflora L., Poincianella pluviosa (DC.) L.P.Queiroz and Commiphora leptophloeus (Mart.) J.B.Gillet were the most common species representing $41.3 \%$ of the total sampled individuals. Cavanillesia arborea (Willd.) K.Schum represented approximately $71 \%$ of ADo in the "furados". This species is a typical tree of caatinga 
on Southern Bahia and Norther Minas Gerais and predominates in karstic soils, which may be considered an indicator of soil quality (Andrade-Lima, 1989).

The plots of forest in deep soil presented 705 individuals of 43 species, with Bignoniaceae representing the most abundant family (291) from a total of 18 families, and Fabaceae as the richest in species (15). Handroanthus ochraceus (Cham.) Mattos, Combretum leprosum Mart. and Arrabidaea bahiensis (Schauer) Sandwith \& Moldenke presented to the highest AD values $(54 \%)$. Due to the large number of individuals, these three species were among the five species with highest values of ADo (Table1).

The species Handroanthus ochraceus (Cham.) Mattos, Acosmium lentiscifolium Schott, Dalbergia cearenses Ducke, C. leprosum Mart. and Casearia selloana Eichl. were indicators of vegetation in deep soil. Acosmium lentiscifolium Schott, Dalbergia cearenses Ducke and C. selloana Eichl. are species restricted to SDTF. In "furados" the species
Pseudobombax simplicifolium A.Robyns and Spondias tuberosa Arruda were indicators of this microhabitat.

Regarding the distribution of individuals in diameter classes, the species Myracrodruon urundeuva Allemão, Poincianella pluviosa (DC.) L.P.Queiroz, Handroanthus ochraceus (Cham.) Mattos, Eugenia uniflora L. and Combretum leprosum Mart. presented similar patterns in the two microhabitats (Fig. 2A-E).

The CCA presented eigenvalues of 0.414 and 0.202 for axes 1 and 2, respectively. The statistically significant edaphic parameters used in the CCA were remaining phosphorus (P-rem), sodium ( $\mathrm{Na}), \mathrm{pH}\left(\mathrm{pH} \mathrm{H}_{2} \mathrm{O}\right)$, coarse sand, clay, depth, potential acidity $(\mathrm{H}+\mathrm{Al})$, base saturation index (V) e zinc (Zn). The CCA plot (Fig. 3) showed species replacement and a separation between microhabitats.

The beta diversity analysis (Fig. 4) also demonstrated that there is a difference in species replacement among microhabitats, with greater replacement recorded for "furados".
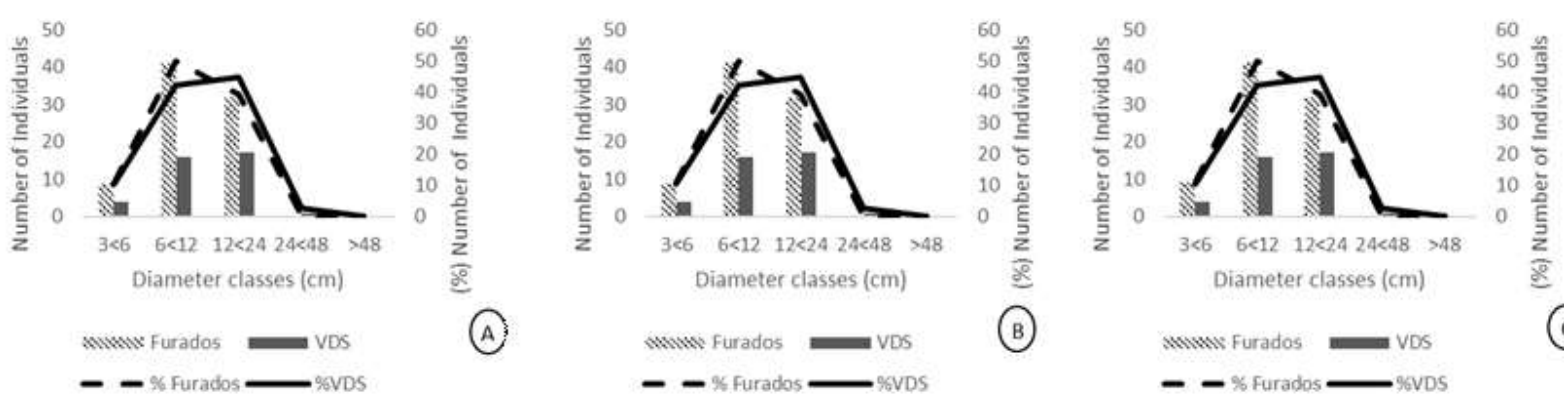

(B)

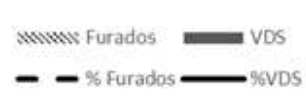

(C)
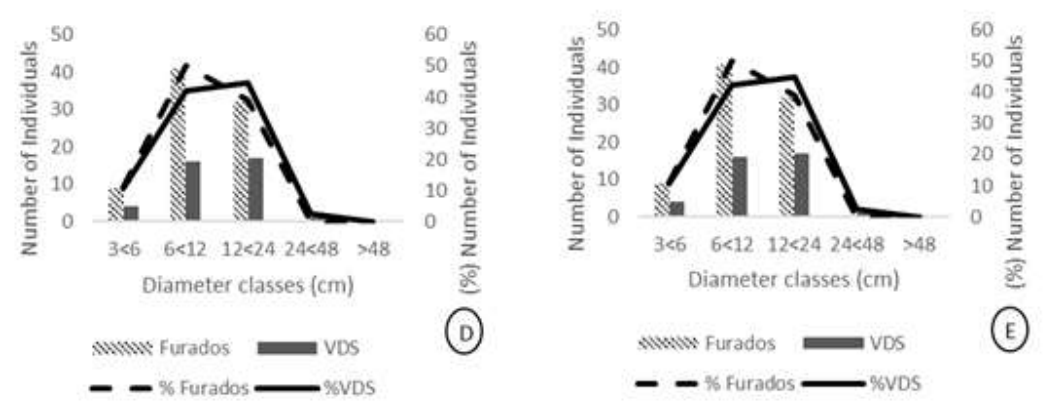

Figure 2 - Diameter distribution of populations with $\mathrm{n} \geq 25$ in one of the two micro-habitats: A. Combretum leprosum; B. Eugenia uniflora; C. Handroanthus ochraceus; D. Myracrodruon urundeuva; E. Poincianella pluviosasampled in the Arboreal Caatinga fragment in Montalvânia, Minas Gerais, Brazil. VDS - Vegetation in Deep Soil.

Figura 2 -Distribuição diamétrica das populações com $n \geq 25$ nos dois microhabitats: A. Combretum leprosum; B. Eugenia uniflora; C. Handroanthus ochraceus; D. Myracrodruon urundeuva; E. Poincianella pluviosasampled em um fragmento de caatinga arbórea em Montalvânia, Minas Gerais, Brazil. VDS-Vegetação em Solo Profundo.

Revista Árvore. 2018;42(2):e420211 


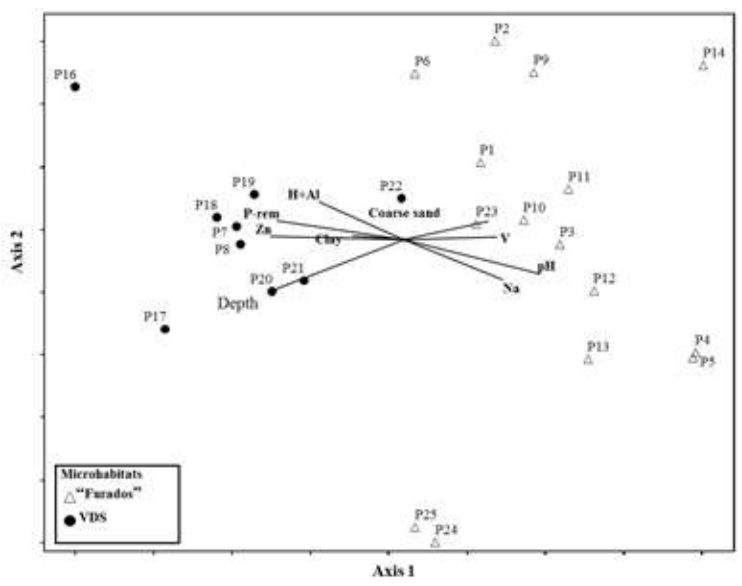

Figure 3 - Ordering diagram produced by the Canonical Correspondence Analysis (CCA) of abundance of 58 species distributed in 24 plots in Montalvânia, Minas Gerais, Brazil, and their relationship with edaphic variables. VDS - Vegetation in Deep Soil.

Figura 3-Diagrama de ordenação produzido por um Analise de Correspondência Canônica (CCA) da abundância das 58 espécies distribuídas em 24 parcelas em Montalvânia, Minas Gerais, Brasil, e sua relação com as variáveis edáficas. VDS - Vegetação em Solo Profundo.

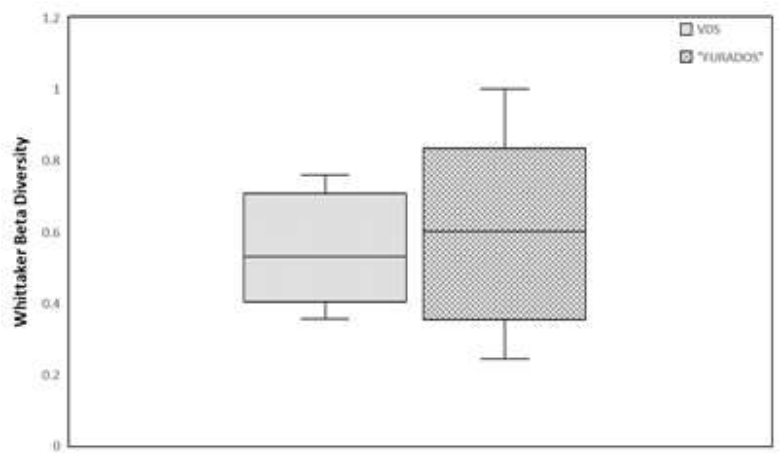

Figure 4 - Beta diversity of microhabitats in a fragment of SDTF, Montalvânia, Minas Gerais, Brazil. VDS - Vegetation in Deep Soil.

Figura 4-Diversidade Beta dos micro-habitats em um fragmento de FTSS, Montalvânia, Minas Gerais, Brazil. VDSVegetação em Solo Profundo.

\section{DISCUSSION}

The microhabitats within the SDTF allied to the water scarcity and pedogeological characteristics provide a high degree of endemism (DRYFLOR, 2016), species replacement and different phytophysiognomies to the landscape. We highlight the "basal area" among the studied phytosociological data (Supplementary Material) because it presented a higher value when compared to other areas of SDTF (Santos et al., 2008, 2011; Siqueira et al., 2009; Felfili et al., 2007). The presence of individuals of Cavallinesia arborea (Willd.) K. Schum. could be the explanation for the high value of absolute dominance, since this species presents dilation on the trunk in function of water accumulation. However, one cannot exclude the influence of climatic and edaphic factors because the species are susceptible to the dynamics of environmental variables (Botrel et al., 2002).

Fabaceae was the botanical family with greater representation among species. Fabaceae is considered a key group to understand the SDTF, which holds the greatest diversity of species in Caatinga, with morphological adaptations for survival in harsh environments (Cardoso and Queiroz, 2011). Features such as the presence of compound leaves with great photosynthetic capacity in favourable periods and seeds with high dormancy and with the power to store nitrogen, which allows a rapid development of the seedlings. Besides having a high metabolism of nitrogen from the symbiotic relationships with bacteria, conferring a greater competitive advantage in the colonization of seasonally dry and oligotrophic environments. The Adaptive success of Fabaceae in the Caatinga is directly related to the ecology and its morphological adaptations. These Features, or morphological adaptations, are directly related to the adaptive success of Fabaceae in the Caatinga

We also highlight the presence of a non-described species in the fragment, Pseudobombax simplicifolium A.Robyns, for which 38 individuals were found in forest plots of "furados". The presence of this undescribed species reaffirms the importance of preservation for forest fragments, mainly in the Caatinga domain which is target of great exploitation and poor legislative protection. Currently these fragments represent relicts and remnants of a diverse and endemic flora. Giulietti et al. (2004) estimates that at least 318 from the 932 species recorded for the Caatinga are endemic.

For a long time the caatinga was considered as the result of the degradation of other plant formations, which produced the false idea that it was homogeneous and composed of few species and with a low index of endemism (Alves, 2007). However, the diversity and equability indexes are lower than those found in humid tropical forests, they do not remove from the caatinga 
their merit and importance as to their richness and diversity. In our study, the Shannon index and Pielou equability demonstrate significant values for the Caatinga, being superior to many other studies (Santos et al., 2007, 2011; Calixto Júnior and Drumond, 2011).

The CCA (Fig. 2) revealed the isolated effect of environmental variables in the community patterns (Capelo, 2003). Featuring eigenvalues of 0.414 and 0.202 for axes 1 and 2 respectively. In this sense, we can affirm that there was a separation of plots into two blocks, which defined the two microhabitats. In addition, the CCA represented a direct relationship between soil depth and species distribution, with plots located on the microhabitat of vegetation in deep soil grouped toward the maximum values of such variable.

The parameters obtained statistical significance and were used in the analysis of CCA were: remaining phosphorus (P-rem), Deph, Clay, Coarse sand, $\mathrm{pH}$, sodium $(\mathrm{Na})$, zinc $(\mathrm{Zn})$, potential acidity $(\mathrm{H}+\mathrm{Al})$, base saturation (V). Among the above parameters, $\mathrm{V}, \mathrm{pH}$ and $\mathrm{Na}$ presented higher mean in the microhabitat of forest in deep soil, however their correlations were better associated to the microhabitat "furados".

The base saturation index (V) is of great relevance within the interpretation of the soil analyzes, since it is used to classify the soils with respect to their fertility (Ernani et al., 2007). Together with the other parameters of the soil analysis, it was possible to define the soil of this fragment as a eutrophic soil, corresponding to a high productivity soil (Ernani et al., 2007). According to Pennington et al. (2000), the good fertility of their soils is one of the main characteristics of FTSS, influencing the species adapted to this adverse environment by water deficiency, but with high natural fertility.

We found a compositional dissimilarity between microhabitats, with greater species replacement recorded for "furados" (Fig. 4). Variations of edaphic conditions frequently associated with topographical position such as depth, chemistry and soil drainage, are clearly one of the main determinants of local floristic variation (John et al., 2007). The presence of limestone slabs influencing mainly the capacity of moisture retention and depth of soil represents a factor of direct influence for the formation of local assemblages. The indicator species (between microhabitats) and graphs of diametric classes reaffirm a difference between microhabitats especially regarding the establishment and survival of species. In this sense, we found that part of the differences in composition and species replacement between microhabitat resulted from the species performance, rather than habitat preference.

Although Cadotte and Tucker (2017) highlight the wrong detection of environmental filters for observational data, the analysis of composition (presence/absence) and abundance of species in our study led to the detection of these filters. We do not exclude the possibility of occurrence of biotic interactions and their respective influence in the formation of assemblages, however the analyzed environmental factors were the main responsible by the structure and composition of microhabitats. The environmental gradient usually generates structural and floristic differences at large scale, meantime at finer scales it is possible to detect the action of environmental filters (Vleminckx et al., 2014).

\section{CONCLUSION}

The observed environmental peculiarities make the "furados" a distinct phytoecological unit within the vast world of Seasonally Dry Tropical Forests SDTF, which shelter species endemic to the caatinga, as Spondias tuberosa Arruda., Pereskia bahiensis Gürke and even undescribed species ( Machaerium sp.). The present study raises our concern for the preservation of SDTF, since the studied fragment is found in a scenario on Northern Minas Gerais - Brazil, weakened by deforestation and neglected regarding environmental issues.

\section{ACKNOWLEDGEMENT}

The project was supported by FAPEMIG. This article was revised during the discipline Scientific Publication in Ecology, Postgraduate in Applied Ecology, Federal University of Lavras.

\section{REFERENCES}

Alves JJA. Geoecologia da caatinga no semi-árido do nordeste brasileiro. Climatologia e Estudos da Paisagem. 2007; 2(1):58-71.

Andrade-Lima D. Plantas das caatingas. Rio de Janeiro: Academia Brasileira de Ciência; 1989. 243p.

Revista Árvore. 2018;42(2):e420211 
Botrel RT, Oliveira-Filho AT, Rodrigues LA, Curi $\mathrm{N}$. Influência do solo e topografia sobre as variações da composição florística e estrutura da comunidade arbóreo-arbustiva de uma floresta estacional semidecidual em Ingaí, MG. Revista Brasileira de Botânica. 2002;24(2):195-213.

Brandão M, Gavilanes ML. Elementos arbóreos ocorrentes no Domínio da Caatinga, no Estado de Minas Gerais e seus empregos. Informe Agropecuário. 1994;17(181):34-42.

Cadotte MW, Tucker CM. Should Environmental Filtering be Abandoned? Trends in Ecology \& Evolution. 2017; 32(6):429-437.

Caetano S, Prado D, Pennington RT, Beck S, Oliveira-Filho AT, Spichiger R, et al. The history of Seasonally Dry Tropical Forests in eastern South America: inferences from the genetic structure of the tree Astronium urundeuva (Anacardiaceae). Molecular Ecology.2008;17(13):3037-222.

Capelo J. Conceitos e métodos da fitossociologia: formulação contemporânea e métodos numéricos de análise da vegetação. Sociedade Portuguesa de Ciências Florestais. 2003. 108p.

Cardoso DBOS, Queiroz LP. Caatinga no contexto de uma metacomunidade: evidências da biogeografia, padrão filogenéticos e abundância de espécies em Leguminosas. In: Carvalho CJBD, Almeida AB, organizadores. Biogeografia da América do Sul: padrões \& processos. São Paulo: Roca; 2011. p.241-60.

DRYFLOR. Plant diversity patterns in neotropical dry forests and their conservation implications. Science. 2016;355(6306):383-1387.

Empresa Brasileira de Pesquisa Agropecuária Embrapa. 2012. [acessado em: 20 jan. 2017] Disponível em: www.bdclima.cnpm.embrapa.br.

Ernani PR, Almeida JÁ, Santos FC. Potássio. In: Novais RF, Alvarez V VH, Barros NF, Fontes RLF, Cantaretti RB, Neves JCL. editores. Fertilidade do solo. Viçosa, MG: SBCS; 2007. p.551-694.

Felfili J, Nascimento ART, Fagg CW, Meirelles EM. Floristic composition and community structure of a seasonally deciduous forest on limestone outcrops in Central Brazil. Revista Brasileira Botânica. 2007;30(4):611-21.
Giulietti AM, Du Bocage Neta AL, Castro AAJF, Gamarra-Rojas CFL, Sampaio E, Virgínio JF, et al. Analise das variações da biodiversidade do bioma Caatinga. In: Silva JMC, Tabarelli M, Fonseca MT, Lins LV. Biodiversidade da caatinga: áreas e ações prioritárias para a conservação. Brasília, DF: Ministério Meio Ambiente; 2004. p.46-131.

Jardim Botânico do Rio de Janeiro - JBRJ. REFLORA. Lista de Espécies da Flora do Brasil. Rio de Janeiro: 2014. [acessado em: 17 jan. 2017]. Disponível em: http://floradobrasil.jbrj.gov.br/ *Calixto Júnior JY, Drumond MA. Estrutura fitossociológica de um fragmento de caatinga sensu stricto 30 anos após corte raso, PetrolinaPE, Brasil. Revista Caatinga. $2011 ; 24(2): 67-74$.

John R, Dalling JW, Harms KE, Yavitt JB, Stallard RF, Mirabello M, et al. Soil nutrients influence spatial distributions of tropical tree species. Proceedings of the National Academy of Sciences of the United States of America. 2007;4(3):864-9.

Kent M, Coker P. Vegetation description and analysis, a practical approach. London: Belhaven Press; 1992.

Moro MF, Lughadha EN, Araújos FS, Martins FR. A phytogeographical metaanalysis of the semiarid caatinga domain in Brazil. Botanic Review. 2016;82(2):91-148.

Mueller-Dombois D, Ellenberg H. Aims and methods of vegetation ecology. New York: John Wiley \& Sons; 1974. 547p.

Oksanen J, Blanchet FG, Kind RT, Legendre P, O'hara RB, Simpson GL, et al. Vegan: Community Ecology Package. R package version 1.17-0. 2010. Available at: http://CRAN.R-project.org/ package= $=$ vegan.

Oliveira Filho AT, Curi N, Vilela EA, Carvalho DA. Variation in tree community composition and structure with changes in soil properties within a fragment of semideciduous forest in south-eastern Brazil. Edinburgh Journal of Botany. 2001;58(1):139-58.

Pennington RT, Prado DE, Pendry CA. Neotropical seasonally dry forests and Quaternary vegetation changes. Journal of Biogeography. 2000;27(2):261-73. 
Pennington RT, Lavin M, Oliveira-Filho AT. Woody plant diversity, evolution and ecology in the tropics: perspectives from seasonally dry tropical forests. Annual Review of Ecology, Evolution, and Systematics. 2009;40(4):437-57.

Prado DE. As caatingas da América do Sul. In: Leal IR, Tabarelli M, Silva JMC, editores. Ecologia e conservação da caatinga. Recife: Universidade Federal de Pernambuco; 2005. p.3-74.

R Development Core Team. R: A language and environment for statistical computing. $\mathrm{R}$ Foundation for Statistical Computing. Vienna: 2015.

Rodal MJN, Martins FR, Sampaio EVSB. Levantamento quantitativo das plantas lenhosas em trechos de vegetação de Caatinga em Pernambuco. Revista Caatinga. 2008;21(3):192-205.

Santos RM, Barbosa ACMC, Almeida HS, Vieira FA, Santos PF, Carvalho DA, et al. Estrutura e florística de um remanescente de Caatinga Arbórea em Juvenílha, Norte de Minas Gerais, Brasil. Cerne. 2011;17(2):247-58.

Santos RM, Oliveira-Filho AT, Eisenlohr PV, Cardoso DBOS, Rodal MJN. Identity and relationships of the Arboreal Caatinga among other floristic units of seasonally dry tropical forests (SDTFs) of north-easter $\mathrm{n}$ and Central Brazil. Ecology and Evolution. 2012;2(2):409-28.

Santos RM, Vieira FA, Fagundes M, Nunes YRF, Gusmão E. Riqueza e similaridade florística de oito remanescentes florestais no Norte de Minas Gerais, Brasil. Revista Árvore. 2007;31(1):135-44.

Santos RM, Vieira FA, Santos PF, Morais VM, Medeiros MA. Estrutura e florística de um remanescente florestal na Fazenda Ribeirão, Município de Juvenília, MG, Brasil. Revista Caatinga. 2008;21(4):154-62.

Scolforo JRS, Mello JM. Inventário Florestal. Lavras: UFLA/FAEPE; 1997.

Silva LA, Scariot A. Composição florística e estrutura da comunidade arbórea em uma floresta estacional decidual em afloramento calcário (Fazenda São José, São Domingos, GO, Bacia do Rio Paranã). Acta Botanica Brasílica. 2003;17(2):305-13.

Siqueira AS, Araújo GM, Schiavini I. Estrutura do componente arbóreo e características edáficas de dois fragmentos de floresta estacional decidual no vale do rio Araguari, MG, Brasil. Acta Botanica Brasílica. 2009;23(1):10-21.

Souza VC, Lorenzi H. Botânica sistemática: guia ilustrado para identificação das famílias de Angiospermas da flora brasileira, baseado na APG II. Nova Odessa: Instituto Plantarum; 2005. 640p.

Ter Braak CJF. Canonical correspondence analysis: A new eigenvector technique for multivariate direct gradient analysis. Ecology. 1988;67(5):1167-79.

Vleminckx J, Morin-Rivat J, Biwolé AB, Daïnou K, Gillet JF, Doucet JL, et al. Soil charcoal to assess the impacts of past human disturbances on tropical forests. Plos One. 2014;9(11):108-21.

Whittaker RH. Vegetation of Siskiyou mountains, Oregon and California. Ecological Monographs. 1960;30(3):279-338.

Zar JH. Biostatistical analysis. 5th ed. New Jersey: Prentice Hall; 2010. 944p.

Revista Árvore. 2018;42(2):e420211 